\title{
PERAN SATUAN POLISI PAMONG PRAJA DALAM UPAYA PENATAAN PEDAGANG KAKI LIMA STUDI KASUS PADA PASAR SERPONG (KECAMATAN SERPONG)
}

\author{
Fahmi Susanti ${ }^{1)}$ \\ 1) dosen universitas pamulang, email : dosen02024@unpam.ac.id
}

\section{ARTICLES INFORMATION}

\section{JURNAL ILMIAH MANAJEMEN FORKAMMA}

\author{
Vol.2, No.2, Maret 2019 \\ Halaman : $1-17$ \\ (C) LPPM \& FORKAMMA
}

Prodi Magister Manajemen UNVERSITAS PAMULANG

ISSN (online) : 2599-171X ISSN (print) : 2598-9545

\section{Keyword: \\ Satuan Polisi Pamong Praja"," Pedagang Kaki Lima", "Peraturan Daerah"}

JEL. classification : M30, M31

Contact Author :

\section{PRODI}

\section{MAGISTER MANAJEMEN \& FORKAMMA UNPAM}

JL.Surya Kencana No.1 Pamulang

Tangerang Selatan - Banten

Telp. (021) 7412566, Fax (021) 7412491 Email :

jurnalforkamma.unpam@gmail.com
Tujuan penelitian untuk menganalisis peranan, andil "Satuan Polisi Pamong Praja" menata pedagang yang berjualan di pinggiran jalan "Pasar Serpong" Kecamatan Serpong", menelaah langkah kegiatan serta usaha yang dilakukan "Satuan Polisi Pamong Praja" dalam menata para pedagang yang berjualan di pinggiran jalan (Pedagang Kaki Lima") "Pasar Serpong" Kecamatan Serpong". Objek yang diteliti ialah "Satuan Polisi Pamong Praja Kecamatan Serpong". Metode penelitian yang dipakai "pendekatan analisis kualitatif" dengan "metode studi kasus". Teknik mengumpulkan data dengan wawancara pada kunci informasi, serta pengamatan langsung pada tempat yang diteliti. Hasil penelitian menunjukkan : peranan "Satuan Polisi Pamong Praja" dalam menata pedagang yang berjualan di pinggiran jalan "Pasar Serpong" sudah dilaksanakan secara baik, "Satuan Polisi Pamong Praja" sudah melakukan ketetapan kewajiban pokoknya, sudah dilakukannya "upaya preventif" (persuasif), "upaya represif" dan "upaya pengawasan". Dapatlah disimpulkan bahwasanya "Peran Satuan Polisi Pamong Praja" dalam menata pedagang yang berjualan di pinggiran jalan "Pasar Serpong" telah dilaksanakan secara baik

The purpose of this study is to analyze The role of Civil Service Police reUnit in conducting the control of street vendors at Serpong Market in Serpong Subdistrict, The efforts made by Civil Service Police Unit in conducting the control of street vendors at Serpong Market in Serpong Subdistrict. The object of this study was street vendors at Serpong Market in Serpong Subdistrict. This study used a qualitative analysis approach with the single case study. The result of study showed that The role of Civil Service Police Unit in conducting the control of street vendors has implemented well, Civil Service Police Unit have performed the basic tasks that had been settled, The efforts that have been done by Civil Service Police Unit are the preventive (persuasive) effort, the repressive effort and monitoring effort. It can be concluded that The role of Civil Service Police Unit in conducting the control of street vendors has implemented well. 


\section{A. Pendahuluan}

Sejak dulu sampai kini hadirnya pedagang di pinggiran jalan "umum" jadi permasalahan yang susah diselesaikan, hingga mengakibatkan perbedaan pendapat, demo serta perselisihan antar individu, bahkan perselisihan antar penduduk sipil dan petugas pemerintahan. Adalah merupakan kebutuhan yang sangat utama untuk semua penduduk akan tentramnya dan tertibnya lingkungan sekitar. Target pertama "Pemerintah" di hampir semua perkotaan ialah mengatur disiplinnya "pedagang Kaki Lima"(PKL)" supaya tidak menimbulkan gangguan-gangguan di masyarakat yang berhubungan erat dengan hal ini ialah "Satuan Polisi Pamong Praja". Dimana memegang andil peranan sangat penting untuk menyokong "Kepala Daerah" dalam menjalani "Pemerintahan Umum".

Pemerintahan "Kota Tangerang Selatan" terutama di "kecamatan Serpong" juga mempunyai permasalahan tentang kehadiran "PKL", dimana apabila "PKL" tidak diatur dan tidak dibina akan memunculkan permasallahan disektor proses pembangunan, keindahan kerapihan, kebersihan kota maupun ,masalah gangguan ketertiban halayak ramai, contohnya terjadinya kemacetan yang menyebabkan ketidaknyamanannya pemakai jalan serta sekitaran lingkungan yang kotor.

Kewiilayahan "pasar Serpong" di jl. Raya Serpong Kecamatan Serpong" merupakan titik yang seringkali terlihat para Pedagang Kaki Lima yang melakukan pelanggaran "ketertiban".

\section{B. Perumusan Masalah}

1. Bagaimanakah peranan "Satpol PP" dalam upayanya menata "pedagang kaki lima" pada "pasar serpong" ?

2. Bagaimanakah "upaya - upaya" yang sudah dilakukan "Satuan Polisi Pamong Praja" dalam menata "pedagang kaki lima" pada "pasar serpong" ?

\section{Pembatasan Masalah}

Dalam penelitian ini peneliti memberikan pembatasan hal diteliti, yaitu peranan "Satuan Polisi Pamong Praja" dalam menata "Pedagang Kaki Lima" "Pasar Serpong" "Kecamatan Serpong"

\section{Tujuan Penelitian}

Adapun tujuan penelitian ini adalah untuk memberikan jawaban atas perumussan masalah:

1. Untuk mengetahui serta menganalisis secara deskriptip bagaimanakah peranan Satpol PP dalam upayanya menata pedagang kaki lima pada pasar Serpong.

2. Untuk mengetahui serta menganalisis secara deskriptip bagaimanakah upaya upaya yang dilakukan "Satuan Polisi Pamong Praja" dalam menata" pedagang kaki lima" pada "pasar Serpong."

\section{E. Manfaat Penelitian}


1. Manfaat teoritis

Secara teoritis penelitian ini diharapkan bisa memberikan sumbangsih pada pengembangan keilmuan dalam hal ilmu "managemen sumber daya manusia" yang dayaguna serta hasil- guna dalam melahirkan pemahaman peranan Satpol PP dalam upayanya menata pedagang Kaki Lima.

2. Secara praktis

a. Bagi Satpol PP hasil yang diteliti bisa dijadikan tambahan bahan pengevaluasian terhadap pelaksanaan "Satpol PP" dalam memajukan lagi peranan, mengimplementasikan Perda tentang penataan Pedagang Kaki Lima.

b. Bagi peneliti lanjutan, hasil yang diteliti dijadikan refferensi, informasi peranan "Satpol PP" di "Kecamatan Serpong" terutama yang berkaitan dengan persoalan pedagang di pinggiran jalan umum , memberikan perbandingan pada hal yang sama.

\section{F. Tinjauan Pustaka}

\section{Manajemen}

"Oey Liang Lee" (Ekonom dari Indonesia) dalam "(Agung Feryanto, 2013:2)" mengartikan "manajemen" ialah keilmuan serta seninya agenda, pengorganisasian, penyusunan, pengarahan, dan pengawasan sumber daya manusia untuk meraih goal ahir. Didasarkan pengertian ini terlihatlah manajemen diamati dari kelangsungan proses, pengkolektifan orangnya, keilmuan, serta kekreatifan profesinya.

\section{Manajemen Sumber Daya Manusia}

Malayu S.P. Hasibuan (2012:9) mengartikan tentang "manajemen sumber daya manusia" sebagai "Ilmu dan seni yang mengatur hubungan dan peranan pegawai agar dayaguna membantu terbentuknya tujuan perusahaan, pegawai dan masyarakat. "

\section{Satuan Polisi Pamong Praja}

Didasari PP Nomor 6 tahun 2010 Pasal 3 tentang Satpol PP, pengertian dari Satpol PP ialah : "Satpol PP merupakan bagian perangkat daerah di bidang penegakan "Perda", ketertiban dan ketentraman masyarakat".

\section{Pedagang Kaki Lima}

Hidayat (2011:31) memberi pendapatnya, "pedagang kaki lima" umumnya ialah "selfemployed, "sebagai kata lainnya ialah "pedagang kaki lima" sebagian besar hanyalah terdiri dari seorang tenaga kerja”.

\section{Kerangka Pemikiran}

Seperti yang diterapkan dalam gambar penelitian ini diawali dari suatu upayanya Satpol PP dalam menjalankan "Perda No 3 tahun 2008 tentang Pengelolaan Pedagang kaki lima (PKL). Langkah Upaya ini dapat dilihat dalam kegiatankegiatannya yang dilakukan "Satpol PP" yaitu tugasnya melakukan penertiban "Pedagang Kaki Lima" yang membuat gagangguan "ketertiban umum." Upayaupayanya" dalam merapihkan "Pedagang Kaki Lima" yang membandel ialah dikategorikanlah dengan "upaya pendekatan persuasive", upaya preventip", upaya 
"represip" dan diterapkannya Standar Oprasional Prosedur (SOP) yang ditetapkan. Dengan menjalani peranannya diharap "Satpol PP dalam merapihkan "Pedagang Kaki Lima" (PKL) dapatlah berlangsung secara baik hingga terbentuknya "ketertiban serta ketentraman umum.

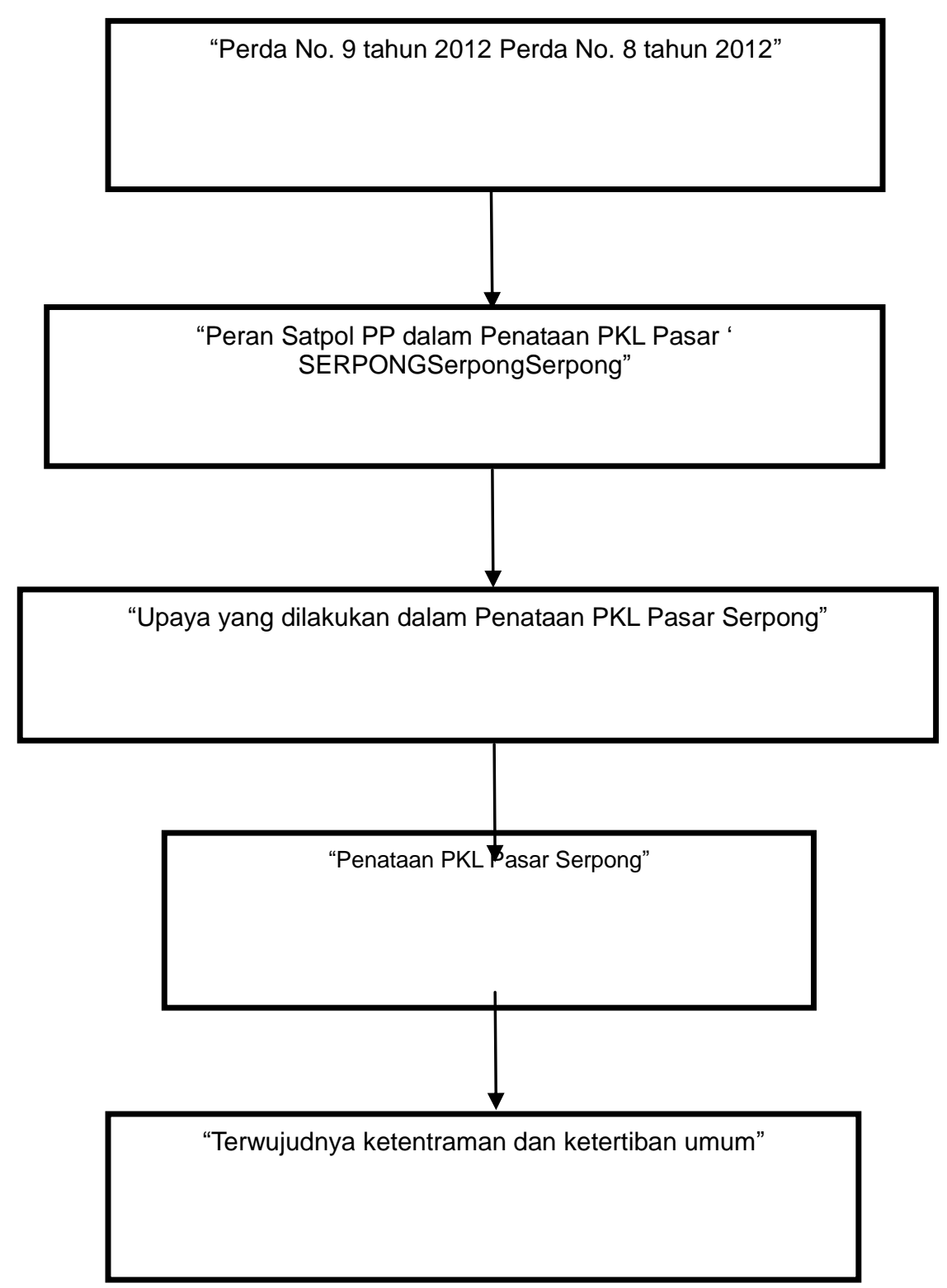




\section{Proposisi Studi}

Hipotesis"ialah penegasan pernyataan/ "proposisi" yang perumusannya untuk dilakukannya pengujian secara nyata di tempat lapangan. "poposisi " disini ialah penegasan pernyataan yang memiliki keluasan cakupan jaringan serta dukungan nyatanya banyak sekali. Berikut perumusan "proposisi ":

a. Bagaimanakah Peranan Satpol PP dalam upayanya menata Pedagang Kaki Lima Pasar Serpong"

b. Bagaimanakah "Upaya" yang sudah dilakukan "Satpol PP" dalam menata Pedagang Kaki Lima" Pasar Serpong

\section{G. Metode Penelitian}

\section{Tempat dan Waktu Penelitian}

Objek di Pasar Serpong yang beralamat di Jl. Raya Serpong Kecamatan Serpong, Tangerang . Ini dilaksanakan selama enam bulan dari proposal dibuat (2017) hingga penelitian selesai dilakukan.

\section{Metode Penelitian"}

Yaitu pendekatan deskriptip kualitatif, dimana bahan yang didapatkan akan dipelajari lebih jauh dan dalam lagi lalu akan dituangkan dalam bentuk cerita narasi metode ini mempunyai ciri tidak menggunakan digit. Metode ini dipakai untuk menggali menyelami bahan kualitatip serta mempelajarinya lalu akan memberikan rekaan sesuatu kejadian terkait peranan "Satpol PP" terhadap PKL.

\section{Populasi dan Sampel}

Populasi di penelitian ini ialah seluruh anggota personil Satuan Polisi Pamong Praja di Kecamatan Serpong

\section{Teknik Penentuan Data}

Sumber data yang diperlukan di penelitian ini :

1. Data primer

2. Data sekunder

\section{Metode Analisis Data}

Metode di penelitian ini ialah:

\section{Validitas Konstruk}

Dengan tujuan terjaminnya validitas data yang didapatkan, di sini peneliti memakai "teknik triangulasi." "Triangulasi" ialah proses untuk pemeriksaan kebeneran sesuatu bahan dengan menggunakan perbandingan dengan bahan yang didapat dari sumber -sumber lainnya, baik saat tahapan penelitian di lapangan, serta pada saat " yang berlainan (Nasution, 2003 :115)." Dalam penelitian ini peneliti menggunakan 2 "teknik triangulasi" yaitu: "trianggulasi sumber" dan "triangulasi metode."

a. Triangulasi sumber

"Triangulasi sumber" artinya ialah peneliti melakukan pembandingan dan melakukan pengecekan lagi posisi kepercayaannya sesuatu penginformasian 
yang didapat deangan cara teknk waktu serta teknik alat yang keseluruhannya berada di "penelitian kualitatif," kesimpulan dari ("Patton dalam Meleong, 2006:330")

b. Triangulasi Metode

Ada dua strateginya ialah dilakukannya pengecekan kembali derajat posisi saat pengumpulan bahan, pengecekan kembali posisi kepercayaan dari beberapa sumber didapatkannya bahan dengan menggunakan pola yang sama. memakai "teknik triangulasi" maka akan dipastikan hasil penelitian yang benar - benar "valid" secara metodologi bisa didapatkan. Kesimpulan dari "Patto dalam (Meleong 2006:331)"

\section{H. Hasil dan Pembahasan}

a). Proposisi

\section{Tugas Satpol PP Dalam Penertiban PKL Pasar Serpong}

Bukti asal Hukum Peraturan Daerah Tangerang Selatan mengenai Situasi Polisi Pamong Praja" dalam menjalankan perannya Satpol PP Kota Tangsel dibekali

a. Perda No 8 Tahun 2012" mengenai "Penataan dan pemberdayaan PKL.

b. Perda No 9 Tahnun 2012" mengenai "Ketertiban umum contioh nya yaitu Penataan pedagang kaki lima "yang tidak patuh aturan dalam Perda no 9 tahun 2002" mengenai ketertiban umum siapapun tidak dianjurkan melaksanakan kegiatan penjual belian di" trotoar, badan jalan serta fasilitas umum lainnya.

c. Adanya Perda No 8 Tahun 2014 mengenai "penataan dan pemberdayaan PKL" akan di maksimalkan dengan cara mendekatkan "PKL", karena antara "Pemerintah Daerah" dan "PKL" memiliki hak dan kewajiban . "Perda No 8 Tahun 2014" menyebutkan "PKL" punya kewajiban yaitu punya bukti surat berusaha, apabila "PKL" ditempatkan di "Faslitas Sosial atau Umum", ketika lahan itu akan dipakai oleh "Pemda" maka "PKL" secara sukarela dan dengan kesadaran harus alih tempat tanpa pengganti kerugian. "Perda No 8 Tahun 2014 pasal 3" kewajiban "Pemerinta kota Tangse"l meliputi mendata "PKL", mendaftarkan "PKL", menentukan tempat berjualan yg baik bagi "PKL", memindahkan tempat "PKL" dan memperbaiki tempat "PKL." Langkah menata ini melewati 3 tahap yaitu peringatan secara" persuasif" , peringatan pertama kali, peringatan kedua kali,serta peringatan ketiga kalinya ,diberikan batas waktu apabila tidak mempedulikan peringatan ketiga kalinya serta telah melewati batas waktunya, "Satpol PP" langsung bertindak tegas yaitu adanya "gabungan".

d. Penegakan Perda ini mengacu pada Perda No 4 Tahun 2014 berkenaan perdagangan dan perizinan.

2. Upaya yang Telah Dijalankan Satpol PP Dalam Penertiban PKL di Pasar Serpong

a. Data Kondisi Satpol PP

1). Sumber daya Satpol PP

a) "Keadaan umum pegawai 
Banyak nya petugas yang ada di satuan polisi pamong praja kecamatan serpong per Pebruari 2014 yaitu 17 petugas meliputi 1 Kasi, 2 Staff " PNS", dan 14 non "PNS."

Penetapan banyaknya anggota selaras dengan perhitungan besarnya pekerjaan. Menurut pemantauan, pelaksanaannya dilokasi banyak titik utama pengamanan dalam "petertiban dan penentraman kemasyarakatan banyaknya anggotapersonil telah sesuai harapan satpol pp kecamatan serpong". Satpol PP Kecamatan Serpong" berupaya melaksanakan kerjasama dengan Badan Kepegawaian Daerah Provinsi Banten didalam hal penambahan anggotanya, selain itu SDM di Satpol PP berusaha untuk menambah "mutu' pengetahuannya, keterampilannya, serta membangun sikapnya polisi pamong praja seperti dalam "peraturan Mentri Dalam Negeri No 38 Tahun 2010" mengenai "pedoman penyelenggaran Diklat Dasar Polisi Pamong Praja"

Untuk menambah mutu"SDM satpol PP" dilaksanakanlah berbagai usaha meliputi" pendidikan dan pelatihan" dasar yang menjadi bukti bentuk terbinanya mutu anggotanya serta "kegiatan "keseharian yang dilaksanakan "satpol PP" misalnya kesempatan untuk menjaga kebuugaran dengan cara olahraga dan latihan "baris-berbaris," membina keahlian anggotanya "satpol PP". Sebagai petugas penegak "peraturan Daerah" kewajiibannya ialah mengikutkan personill "satpol PP" dalam " pelatihan ", seminar dan rapat kerja. Menurut hasil tanyajawab anggota "Satpol PP Kecamatan Serpong " biasanya dapat undangan untuk pelatihan di "Satpol PP Kota Tangerang Selatan ", setahun sekali tapi pesertanya dibatasi. Undangan untuk rapat kerjapun kekerapannya sering, undangan berasal dari "Satpol PP Kota Tangerang Selatan.

Tingkatan "pendidikan" 17 anggotanya Satpol PP Kecamatan Serpong yaitu "PNS "1 orang anggota S1, 1 anggota D3, 13 anggota SLTA, dan 2 anggota SLTP.Berdasarkan pendidikan "SDM satpol PP Kecamatan Serpong" masih didominasi pendidikan SMA.Keadaan ini memperlihatkan sisi kebutuhan memahami tugas yang semakin berat, dibutuhkan penambahan mutu "pendidikan" maupun keahlian "SDM" yang diinginkan dengan hajat bisa mengimbangi tugas "satpol PP" sebagai petugas yang menyelenggarakan penertiban ,penentraman serta memberikan perlindungann serta menegakkan "Perda" aturan pelaksanaan nya.

b) Data Sarana Prasarana

Dukungan kendaraan, meliputi 1 mobil patrolli serta 2 "kendaraan roda 2"(dua). Keadaan kendaraan nya masih bisa digunakan untuk menyokong terlaksananya " peran tugas" "satpol pp" tetapi keadaan nya tidak layak sebab itu perlu pergantian kendaraan.

Selain itu satpol PP dilengkapi sejumlah peralatannya yang lain seperti 5 Gegep(tang), 1 tangga aluminium, 6 tameng, 2 lampu "lalu lintas", serta 2 "handy talk". Keadaan peralatan tidak layak pakai, terutama alat komunikasi dalam membantu tugas dilapangan, dan "Satpol PP kecamatan Serpong" belum punya perbekalan penyokong saat melaksanakan tugas 
mendadak, maka perlunya perawatan teratur dan butuh diadakan perbekalan untuk tugasnya yang "mendadak"serta perlunya pembeliian perbekalan baru.

b. Data usaha yang telah dilaksanakan dalam penertiban PKL di pasar serpong"

1) Pemeliharaan ketertiban umum dan ketentraman masyarakat Dengan maksud yaitu:

a) Didapatnya kesempatan berusaha bagi "PKL" lewat penentuan lokasi sesuai peruntukan nya

b) Memacu menumbuhkan serta memperluas kemampuann usaha "PKL" menjadi tangguhnya usaha

c) Melahirkan kota 'bersih', "indah", "tertib”, serta “ aman” di dukung “ sarana prasarana "kota yang berbobot

Dalam mempraktikkan peraturan Daerah serta mengawas serta mentertibkan halayak Satuan polisi pamong praja selalu mengikutkan "penegak hukum" utamanyakepolisian ditingkat daerah, "OPD provinsi" serta "Satuan polisi pamong praja kota" dan "OPD kebupaten/kota" . Langkah "satpol pp" menindaki pelanggar bisa dikategorikan jadi 3 yaitu:

a) Upaya /langkah Preventif(persuasif)

Upaya/langkah preventif" yang diterrapkan "satpol pp" meurut "perda No 54 Tahun 2011" yaitu:

1) Dilakukan pembentukan aturan berlaku, berkaitan dengann sistem prosedural, hubungan serta tata-nyakerja

2) Dibuat panduan sesuai penetapan aturan

3) Dilakukan pembentukan kedudukannya, tugasnya, wewenangnya serta tanggung jawabnya

4) Mengatur semua kegiatannya, pengelompokan kerjaan, pengawasannya

5) Dibentuk sistematis kerjasamanya, pelaporannya serta pemeriksaannya.

\section{1) Penegakan Peraturan Perundang-Undangan Daerah}

Rintangan dimasa datang yang pasti akan terjadi dan harus kita untuk dihadapi ialah hal-hal yang berkenaan dengan menegakkan "peraturan daerah"serta terelaksananya keadaaan yang nyaman, aman serta kebiasaan karakter disiplin dalam kehidupan besama yaitu keadaan makin menjamurnya "Pedagang Kaki Lima", dan penduduk masih kurang sadar warga daengan "Peraturan Daerah". "Satpol PP" yang punya kedudukan satu-satunya menjadi alat perangkatan di Lingkungan "Pemerintah Daerah" 
2) Terapan Standar Operasional Prosedur (SOP)

a) Standar Operasional Prosedur Penegakan Peratuan Daerah Satuan Polisi Pamong Praja

(1) Lingkupannya yaitu :

(a) Terselenggaranya pemahaman kepada kepada penduduk, ,ke lembagaan yang berkaitan dengan hukum, petugas petugas pemerintah, yang melanggar "Perda"

(b) Pelatihan bimbingan serta penyosialisasian

(c) Kegiatan untuk mencegah dengan cara yang tidak berhubungan denagn "hukum"

(d) Kegiatan dengan cara yang berhubungan dengn " hukum"

(2) Pelaksanaan

Dipadukan beberapa golongan yaitu "Satpol PP", pejabat yang punya keberwenangan, dari "kepolisian" "(Korwas PPNS)", "Pengadilan" "Kejaksaan". Hal yang dapat diperbuat oleh "Pengadilan" serta " Kejaksaan" yaitu :

a) Penyidangan untuk semua pelanggar PERDA Menyiapkan berkas semua pelanggar peraturan daerah lalu dilanjutkan penyerahannya ke kejaksaan. Tahap berikutnya kerjasama kepada "kejaksaan", "kepolisian (Korwas PPNS"), serta "Pengadilan" setelah itu disusun jadwal penyidangan ditempat bagi semua pelanggaran "peraturan daerah.

b) Petunjuk Teknis Standar Operasional Prosedu"r Pelaksanaan Patroli Sebelum pelaksana berjalan wajib periksa kelengkapan perbekalan "patroli" pejalan kaki:

- Dimulai sejak keluar kantor.

- Sedikitnya 2 oraang

- Keliling Mematroli di siang hari di poin kerawanan seperti pertokoan serta "pasar"

- Harus hpaal dan kenal lokasi "patroli."

- Melakukan perekaman pelaporran saat berkeliling untuk diserahkan ke pimpinannya .

- Cekatan dan cepat saat ada kejadian luar biasa ataupun kebakaran ialah menjadi kewajibannya.

- Semua pengambilan tindakan saat penugasan harus berpegang dengan penetapan protokol Berkeliling memakai motor :

- Contoh baik harus diperlihatkan oleh anggota, diperuntukkan bagi warrga pengendara lainnya..

- Menurut serta menaati aturan "lalu lintas."

- Kecepatan sewajarnya saat menjalankan kendaraannya

- Sepatutnya tidak membunyikan klakson atau sirine kecuali sangat diperlukan sekali.

- Tidak dibolehkan sorotan berlebihan lampu motor saat malam 


\section{Pembahasan}

\section{Peranan Satpol PP di Kecamatan Serpong dalam Penataan PKL}

(a) Acuan pada waktu menjalani peranannya, "Satuan Polisi Pamong Praja" yaitu berpegang dengan protocol "perundang-undangan" bisa dalam bentuk "peraturan pemerintah" konteks nasional ataupunn "peraturan-peraturan daerah" dalam menjalani wewenangnya serta haknya berhubngan dengan menegakan "peraturan daerah". Hal ini bisa ditempuh dengan berpegang pada pelaksanaan prosess "Operasional nya Terbina Kedamain Umum" bekerja bersama-sama dengan personil

a. lainnya. Sudah dijalankannya penerapan hukuman terhadap pelanggar "peraturan daerah" "Kecamatan Serpong" tapi masih belum maksimal. Penyebab hal ini yaitu dari segi mutu anggota "Pemerintah Daerah'. Penyebab lainnya ialah proses jatuhnya hokum kepada semua pelanggarr. Adapun semuanya diatur serta berdasar "Hukum Peraturan Daerah (Perda) Kota Tangerang Selatan" tentang "Satuan Polisi Pamong Praja" pada saat menjalani tugassnya. "Satpol PP" Kota Tangerang Selatan dibekali oleh "Perda":

b. No. 8 Tahun 2012 tentang Penataan dan Pemberdayaan "PKL".

c. Peraturan Daerah (Perda) No 9 Tahun 2012 tentang Ketertiban Umum." Didalamnya terdapat salah satunya yaitu "penertiban pada Pedagang Kaki Lima" (PKL) yang tidak patuh dengan protocol berlaku . ini ada di dalam "Perda Nomor 9 tahun 2012 perihal Ketertiban Umum" untuk semua siapa pun tidak boleh melakukan kegiatan jual beli di trottoar, badannya jalan serta perangkat umumm lainnya

d. Pemaksimalan Perda No 8 Tahun 2014 mengenai Penataanserta pemberdayaan $\mathrm{PKL}$ dengan salah satu cara yaitu pendekatan yang tidak pakai kekerasan pada "PKL" karena semuanya punya hak dan kewajibannya masing - masing antara "Pemerintah Daerah"dan "PKL". Dalam "Perda" No 8 tahun 2014 tersebut "PKL" mempunyai keharusan untuk punya surat keterangan tanda usaha, andai "PKL" diposisikan di "fasos dan umum", pada suatu saat tempat itu akan digunakan kembali oleh "Pemda" maka "PKL" mau secara sukarela

e. harus pindah tanpa ada ajuan pengganti kerugian. Sedangkan kewajiban "Pemerintah Kota Tangerang Selatan" dalam "Perda" tentang "PKL" No 8 tahun 2014 pasal 3 ialah membukukan "PKL", mendaftarkan "PKL", mencarikan lokasi "PKL", memindahkan wilayah jual beli "PKL" serta membaharui wilayah jual beli "PKL". Ada tiga langkah ketertiban yang dilaksanakan yaitu dengan teguran yang pertama dengan secara membujuk tanpa memakai cara kekerasan, seminggu yang akan datang kalau masih membandel dilayangkan surat atau dengan cara lisan " 
teguran kedua. Kalau masih saja terabaikan serta masih membandel saat seminggu kedepan dilayangkan surat teguran atau secara lisann yang ketiga, kalau masih tidak mengindahkan atau telah mengacuhkan teguran ketiga dan sudah melewati kurun waktu yang ditetapkan maka Satpol PP melakukan tindakan "eksekusi" atau dikenal dengan gabungan.

f. Menegakan Perda ini berpegang pada Perda No 4 Tahun 2014 tentang Perdagangan dan Perizinan."

\section{Upaya yang sudah dilakukan Satpol PP dalam menata PKL di Pasar Serpong}

dalam menindaklanjuti para pelanggar kegiatannya personil "Satpol PP" bias dikelompokkan jadi 3 urutan tahapan yaitu :

a. Upaya / Tindakan Pencegahan (Persuasif)

Usaha ini yang seharusnya diterapkan anggota "Satpol PP" berdasarkan "Perda nomor 54 tahun 2011" yaitu :

a) Melakukan pembentukan peraturann yang sudah diberlakukan serta berkenaan dengan urutan aturan, tautan serta penataan kerja

b) Menyusunkan panduan tertulis yang sesuai prottokol seharusnya

c) Melakukan pembentukan posisi,penugasan, keberwenangan serta pertanggungan jawab.

d) Mengelola semua dan pembagian pekerjaan, kegiatannya, alokasi penempatan, pengontrolan

e) Melakukan kerjasama, di pelaporan serta pemeriksaan

f) " upaya"/ tindakan pencegahan yang sudah dijalankan di pelaksanaan yang ada di tempat kejadian ialah dilakukannya pengarahan secara "persuasi" tidak adanya kekerasan tiap bulan sekali . Contoh nyatanya anggota "Satpol PP" ber- diskusi dan bertukar pendapat.

b. Upaya Represif (Penindakan)

Dilaksanakan oleh Kepala Pasar dalam mencari tempat untuk pemindahan "Pedagang Kaki Lima." Pemindahan yang disediakan untuk "PKL" "pasar Serpong" adalah bertempat di dekat stasiun "Kereta Api Serpong "(100 m dari pasar serpong)

c. Upaya Pengawasan

Akan diberikan hukuman terhadap pengabaian atau melanggar dari aturran. Diantaranya yaitu apabila masih ada "PKL" membandel maka akan dilakukan tindakan pengusiran, jika tahap ini masih diabaikan akan diberikan teguran langsung maupuntulisan surat.. Jika terbukti masih membandel akan diberikan tindakan "non yustisial" atau "yustisial" lalu diserahkan ke "pengadilan". Di Kegiatan gabungan ini "Satpol PP Kecamatan Serpong" berkerjasama dengan "Satpol PP Kota Tangerang Selatan"," Kepolisian" ," Dinas Kebersihan" dan 
"instansi terkait lainnya". Seperti telah disebutkan bahwa sebelum dilakukan "gabungan" "Satpol PP Kecamatan Serpong" memberikan "upaya persuasip", berupa teguran tertulis ataupun teguranlangsung sebanyak tiga kali dalam kurun waktu seminggu utk setiap surat, jika ini diabaikan oleh pelaku jual beli maka "Satpol PP Kecamatan Serpong" berkerjasama dengan dinas terkait lainnya untuk melakukan ekekusi/"gabungan"

Saat Kegiiatan "gabungan "Satpol PP Kecamatan Serpong " hanya berperan sebagai pendamping, pemberi instruksi adalah Pimpinan "Satpol PP Kota Tangerang Selatan". "Dinas kebersihan" perananya yaitu menampung dan mengangkut semua peralatan berdagang si pelanggar. Barang serta alat pendukung untuk berjualan tersebut dibawa serta dikumpulkan di Kantor " Satpol PP Kota Tangerang Selatan". Para pelaku "(PKL)" yang barang dagangannya dan peralatannya disita saat itu disanjurkan oleh "Satpol PP" untuk datang dengan membawa kartu pengidentitas diri lainnya untuk mengambil barang-serta alat alat dagangnya di kantor "Satpol PP Kota Tangerang Selatan". Mereka /pelanggar akan diberikan pembimbingan supaya tidak mengulangi peerbuatan yang sama yaitu berjualan di pinggir jalan "Pasar Serpong".

(Pada Satpol PP Kecamatan Serpong "hampir semua penindakan "pengawasan" sudah dilaksanakan. Tindakan "pengawasan"yang belum dilaksanakan adalah memberikan "hukuman pengadilan" )

Dalam Pelaksanaan tugasnya "Satpol PP" Kecamatan Serpong belum menerapkan "SOP" secara keseluruhan. Faktor yang mempengaruhi belum diterapkannya "SOP" secara keseluruhan. penyebabnya masih kurangnya pendidikan anggota "Satpol PP" serta " sarana prasarana" yang kurang menyokong. Berdasar hasil tanyajawab penelitian dengan Pimpinan "Satpol PP" "Kasie Tantib Kecamatan Serpong" (tanggal 4 Maret, 16 Maret dan 4 Mei 2018). Salah satu faktor yang paling berpengaruh terhadap usaha peningkatan kemampuan kerja "Satuan Polisi Pamong Praja" ialah "sumber daya manusia" dimana "pendidikan pelatihan" jarang dilakukan, masih ada anngota yang kurang sigap menjalani tugasnya dalam hal "penegakan peraturan daerah Masih kurangnya juga pengembangan anggota mengakibatkan hasil kerjaan "Satuan Polisi Pamong Praja" kurang memadaidan kurang mantapnya dalam menegakkan "peraturan daerah". Hal ini sejalan dengan pendapat para ahli yaitu "Sumber daya aparatur Satuan Polisi Pamong Praja" tidak saja harus memadai tetapi juga diperlukan kemampuan serta "kebutuhan kemanajemen".Maka dapat disimpulkan bahwa kelemahan yang terjadi akibat kurangnya mutu "SDM "anggota "Satuan Polisi" S, Sudjana, D., dan Rasjidin," W (Penyunting)." "IImu dan Aplikasi Pendidikan Bagain IV Pendidikan Lintas Bidang. Bandung: PT Imperial Bhakti Utama (Halaman 372-387)".

Melemahnya mutu "SDM Pamong Praja" menyebabkan keberhasilan menegakan "peraturan daerah" akan sulit dicapai, dan keunggulan" SDM" "Satuan Polisi Pamong Praja" akan menghasilkan kerjaan dalam menegakan "peraturan daerah" yang kurangtinggi. Untuk mengukur hal-hal yang berhubungan "Sumber Daya Manusia" "Satpol PP" Kecamatan Serpong, 
dengan melihat dari sisi pendidikan. Adapun keterkaitan pemahaman anggota "Satpol PP" mengenai "Perda" di" Kecamatan Serpong" dapat dilihat dari tingkat pendidikan, sangat terlihat jelas bahwa umumnya anggota "Satpol PP" "Kecamatan Serpong" berpendidikan setingkat "SMP/SMA" hingga pemahaman anggota "Satpol PP" terkait jumlah "Peraturan Daerah" sangatlah sedikit, sedangkan anggota akan menegakkan "peraturan daerah" yang banyak sekali.

Berdasar hasil tanyajawab penelitian dengan bapak Pimpinan "Satpol PP" "Pemerintah Kecamatan Serpong" (tanggal 4 Maret, 16 Maret dan 4 Mei 2018). (terlampir). Saranaprasarana "Satuan Polisi Pamong Praja" sangat lah berperanan penting untuk menaikkan mutuhasil dan mutu kerja "Satuan Polisi Pamong Praja" tersebut. Mengapa demikian, karena dalam menjalankan tugasnya dengan perbekalan yang sudah ada, maka secara langsung "kinerja Satuan Polisi Pamong Praja" tersebut akan meningkat dan sebaliknya, jika perbekalan kerja tidak memadai dalam pelaksanaan tugas maka akan menurunkan mutu kerjanya anggota. "Hasibuan (2010:10)" 


\section{J. Kesimpulan dan Saran}

\section{Kesimpulan}

a) Peranan Satuan Polisi Pamong Praja dalam perapihan Pedagang Kaki Lima pada pasar Serpong cukup berperan penting karena "Polisi Pamong Praja" sudah menjalani tugasnya yang telah ditetapkan dan diharuskan. Namun, "upaya penataan pedagang kaki lima" pada "pasar Serpong" belum sepenuhnya terlaksanakan dengansetingi-tingginya. Hal tersebut dikarenakan mutu pendidikan" SDM" "Satpol PP Kecamatan Serpong" "yang lebih banyak "SMA", hingga keterampilannya anggota belum semaksimal seperti yang diharapkan.

b) Satuan Polisi Pamong Praja sudah melakukan upaya-upaya dalam "penataan PKL" pada "pasar serpong," sesuai dengan tugas utamanya membantu Walikota dalam menjalani "Pemerintahan di Bidang Ketentraman dan Ketertiban masyarakat" serta penegakkan "Perda nomor 54 tahun 2011."

Berikuit "Upaya "yang dilakukan:

a. Upaya / Tindakan Pencegahan ( Persuasif).

1) Melakukan pembentukan aturran berlaku berkenaaan dengan tahapan, dan penataan pekerjaan

2) Menyusun panduan sesuai prottokol

3) Melakukan pembentukan posisi, penugasan, keberwenangan serta pertanggung jawaban.

4) Melakukan pengorganisasian semua kegiatannya, penempatannya, pengawasannya serta pengelompokan pekerjaannya

5) Melakukan pembentukan pemeriksaan, pengkoordinasian, laporannya

6) Di tempat kejadian, kegiatan yang sudah dilakukan dalam hal mencegah ialah pengarahann serta pendekatan perindividu dalam kurun waktunya sebulan untuk tiap teguran. Contoh kegiatan konkritnya yaitu tukar pendapat.

b. Upaya Represif (Penindakan)

Dilaksanakan oleh Kepala Pasar dalam mencari tempat untuk memindahkan "Pedagang Kaki Lima." Tempat pemindahan yang disediakan untuk "PKL" "Pasar Serpong" berada di dekat Stasiun "Kereta Api Serpong "( 100m dari pasar Serpong ).

c. Upaya Pengawasan

Pemberian hukuman kalau menyimpang ataupun mengabaikan atuuran.

Kalau masih ada "PKL" yang membandel selanjutnya dilakukan perapihan / pembersihan secara paksa "pengusiran, "kalaupun tahapan ini masih diabaikan maka diberikan tegurann langsung ataupun dengan tertulis. Tindakan "non"hukum atau tindakann "hukum" yaitu perkaranya tersebut 
diserahkan ke "pengadilan" kalau masih melakukan pengabaian terhadap peringatan "teguran".

( Hampir semua tindakan pengawasann telah dilaksanaka di "Satpol PP Kecamatan Serpong". Tindakan yang belum dilaksanakan adalah memberikan hukuman terhadap pengabaian atturan)

\section{Saran}

a) Untuk menambah tingkat kemampuan keterampilannya dilapangan pekerjaannya, haruslah memperbanyak lagi pengiriman anggota Satuan Polisi Pamong Praja" dalam "diklat-diklat " dalam usaha memajukan " mutu pendidikan anggota Satuan Polisi Pamong Praja”.

b) Pemerintah Kota Tangerang Selatan" harus menyediakan media yang lebih proporsiional untuk "Satpol PP". Seperti penambahan jumlah kendaraan patrolinya, perawatan kendaraan berkeliling agar kondisinya tetap prima dan lakukan penggantian kendaraan tersebut apabila kondisinya sudah tidak layakpakai lagi. Selain kendaraan berkeliling, "pemerintah" harus menambah jumlah media kerja(gegep, tangga alumunium, tameng, lampu lalu lintas, handy talky) dan melengkapinya suppaya anggota "Satpol PP" bisa lebih baik lagi dalam menjalankan tugasnya 


\section{K. Daftar Pustaka}

FeryantoAgung.2013:2.Seri Ensiklopedia IPS Materi EkonomiManajemen Vol 7.Klaten:Cempaka Putih

Hasibuan. 2011ManajemenSumber Daya Manusia. Jakarta: Bumi Aksara

Hidayat.2011.Metode Penelitian Keperawatan dan Teknik Analisa Data . Jakarta : Salemba Medika

Moleong, Lexy. 2006. Metodologi Penelitian Kualitatif. Bandung: PT. Remaja Rosda Karya

Nasution. 2003. Metode Penelitian Naturalistik Kualitatif. Bandung: Tarsito

\section{Jurnal}

Ahmad Zamahsari. 2017. Resolusi Konflik Pedagang Kaki Lima (PKL) di Pasar Tanah Abang Provinsi DKI Jakarta (Conflict Resolution the Street Vendors (PKL) in Pasar Tanah Abang in DKI Jakarta). Jurnal Prodi Damai dan Resolusi Konflik Juni 2017 Volume 3 Nomor 2. Universitas Pertahanan

Aldi Juliant Loebaloe. 2015. Peran Satuan Polisi Pamong Praja dalam Menertibkan Pedagang Kaki Lima di Kota Denpasar. Universitas Udayana

Dhoni Muttaqien, 2012, Kinerja Satuan Polisi Pamong Praja dalam Menegakkan Peraturan Daerah di Kecamatan Rangkasbitung Kabupaten Lebak, Universitas Sultan Ageng Tirtayasa Serang

Apriaji Setiawan. 2017. Peran Satuan Polidi Pamong Praja (SATPOL PP) dalam Menertibkan Pedagang Kaki Lima (PKL) di Kawasan Tepian Mahakam Kota Samarinda. eJournal Administrasi Negara Volume 5 , (Nomor 3 ) 2017: 6129-6142 ISSN 0000-0000 (ejournal.an.fisip-unmul.ac.id)

Apriaji Setiawan. 2017. Peran Satuan Polisi Pamong Praja (Satpol PP) dalam Menertibkan Pedagang Kaki Lima (PKL) di Kawasan Tepian Mahakam kota Samarinda Universitas Mulawarman

Eko Budi Sulistio . 2012.Analysis and policy Design of street vendor Management of Bandar Lampung. International Journal of Administrative Science \& Organization, September 2012 Volume 19, Number 3

Elza Syarief, Wagiman dan Raha Syaiful Anwar. 2014. Peranan Satuan Polisi Pamong Praja Dalam Melaksanakan Penegakan Peraturan Daerah ( Studi terhadap Implementasi Standart Operasional Prosedur ( SOP) Satpol PP Provinsi Kepulauan Riau. CJournal Of Judicial Review. Vol.XVI No.12 Juni 2014

\section{Undang-Undang dan Perda}


Himpunan Peraturan Perundang-Undangan. 2010. Satuan Polisi Pamong Praja (Satpol $P P)$ dan Peraturan Pelaksanaannya. Bandung: Fokusmedia

Himpunan Peraturan Perundang-Undangan. 2011. Satuan Polisi Pamong Praja (Satpol PP) dan Peraturan Pelaksanaannya. Bandung: Fokusmedia

UU Republik Indonesia Nomor 32 Tahun 2004 Tentang Pemerintahan Daerah pada Pasal 1 ayat (2) dan pada Pasal 148 ayat (1)

Peraturan Pemerintah Republik Indonesia Nomor 32 Tahun 2004 Tentang Satuan Polisi Pamong Praja

Peraturan Menteri Dalam Negeri Nomor 26 Tahun 2005 Tentang Prosedur Tetap Operasional Satuan Polisi Pamong Praja

Peraturan Menteri Dalam Negeri Nomor 38 Tahun 2010 Tentang Pedoman Penyelenggaraan Diklat Dasar Polisi Pamong Praja 